\title{
Kajian Pengatahuan Mahasiswa Apikes Citra Medika Surakarta Mengenai Manfaat Teh Rambut Jagung untuk Pencegahan dan Pengobatan Diabetes Melitus
}

\author{
Studies Student's Knowledge at Apikes Citra Medika Surakarta About Corn Silk Tea on The Benefits \\ for The Prevention and Treatment of Diabetes Melitus
}

\author{
Liss Dyah Dewi Arini* dan M. Eka Hidayatullah \\ APIKES Citra Medika Surakarta \\ *Corresponding author: leeansz fortune@yahoo.com, ekahidayat76@gmail.com
}

\begin{abstract}
ABSTRAK
Diabetes adalah salah satu penyakit yang paling sering diderita dan penyakit kronik yang serius di Indonesia saat ini. Rambut jagung mengandung komponen bioaktif flavonoid, Saponin, Tanin, Phlobatanin, Fenol, Alkaloid, dan Glikosida jantung. Komponen tersebut merupakan senyawa yang ditemukan pada ekstrak rambut jagung dan berkontribusi terhadap bidang farmasi. Tujuan penelitian adalah untuk mengetahui tingkat pengetahuan mahasiswa khususnya di APIKES Citra Medika Surakarta mengenai manfaat teh rambutjagung untukpencegahan dan pengobatan Diabetes Melitus. Metode yang digunakan adalah penelitian non eksperimen dengan menggunakan analisis deskriptif dan dengan cara memberi kuesioner. Hasil dari penelitian ini adalah dari dua puluh sampel mahasiswa Apikes Citra Medika Surakarta yang telah mengisi kuesinoner untuk tiga belas pertanyaan diperoleh data sebagai berikut : sebagian besar mahasiswa sudah mengetahui tentang penyakit Diabetes Melitus dan manfaat teh rambut jagung yang natara lain dapat bermanfaat untuk kesehatan yaitu mencegah dan mengobati penyakit Diabtes Melitus. Selain hal tersebut ternyata sebagian bersar mahasiswa merasakan manfaat nyata dari konsumsi the rambut jagung selama tiga hari, yaitu terjadi penurunan kadar gula darah, tidak cepat nagantuk, tidak cepat lelah dan tidaksering buang air kecil pada malam hari. Mahaiswajuga sangat antusias terhadap pengembangan pengetahuan mengenai manfaat teh rambut jagung untuk pencegahan dan pengobatan Diabates Melitus.
\end{abstract}

Kata kunci : Pengetahuan, manfaat, teh rambut jagung, Diabetes Melitus

\begin{abstract}
Diabetes is one of the most common diseases and serious chronic diseases in Indonesia today. Corn hair contains bioactive components of flavonoids, saponins, tannins, phlobatanin, phenol, alkaloids, and cardiac glycosides. These components are compounds found in corn hair extracts and contribute to the pharmaceutical field. The purpose of the study was to determine the level of student knowledge, especially at APIKES Citra Medika Surakarta regarding the benefits of corn hair tea for the prevention and treatment of Diabetes Melitus. The method used is non-experimental research using descriptive analysis and by giving a questionnaire. The results of this study were from twenty samples of Apikes Citra Medika Surakarta students who had filled in the questionnaire for thirteen questions, the following data were obtained: most students already knew about Diabetes Mellitus and the benefits of corn hair tea which could be beneficial for health. and treat Diabtes Melitus. In addition to this it turns out that some students feel that there are real benefits from consuming corn hair for three days, which is a decrease in blood sugar levels, not fast drowsiness, no fatigue and frequent urination at night. Students were also very enthusiastic about developing knowledge about the benefits of corn hair tea for the prevention and treatment of Diabates Melitus.
\end{abstract}

Keywords: Knowledge, benefits, corn hair tea, diabetes Melitus

\section{PENDAHULUAN}

Diabetes Melitus (DM) adalah salah satu penyakit yang paling sering terjadi dan merupakan penyakit kronik yang serius di Indonesia pada saat ini. Diabetes Melitus adalah suatu kelompok penyakit metabolik dengan cirri khas yaitu hiperglikemia yang terjadi akibat kelainan sekresi hormon insulin, kerja hormon insulin atau keduanya (Gustaviani, 2006). Hiperglikemia kronik pada diabetes berhubungan erat dengan kerusakan jangka panjang, disfungsi atau kegagalan beberapa 
organ tubuh, terutama pada organ mata, ginjal, saraf, jantung dan juga pembuluh darah (Gustaviani, 2006). World health organization (WHO) merumuskan bahwa DM merupakan suatu penyakit yang tidak dapat dipecahkan dalam satu jawaban yang jelas dan singkat tetapi secara umum dapat dikatakan sebagai suatu kelompok masalah anatomi dan kimiawi yang terjadi karena sejumlah faktor dimana terjadi defisiensi hormone insulin absolut atau relatif dan gangguan fungsi hormone insulin itu sendiri (Arisman, 2011).

Setengah dari jumlah kasus Diabetes melitus tidak terdiagnosa karena biasanya diabetes tidak disertai gejala sampai terjadinya komplikasi. Prevalensi penyakit diabetes meningkat dari tahun ke tahun dikarenakan terjadinya perubahan gaya hidup (life style), kenaikan jumlah kalori yang dikonsumsi, kurangnya aktivitas fisik (olahraga) dan meningkatnya jumlah populasi manusia usia lanjut. Karena semakin majunya keadaan sosio ekonomi masyarakat Indonesia serta pelayanan kesehatan yang semakin baik dan merata, diperkirakan tingkat kejadian penyakit diabetes Melitus (DM) akan semakin meningkat. Penyakit ini dapat menyerang segala tingaktan umur dan sosio ekonomi. Dari berbagai penelitian epidemiologis di Indonesia diperoleh prevalensi sebesar $1,5-2,3 \%$ pada penduduk usia lebih besar dari 15 tahun. Pada suatu penelitian di Manado didapatkan prevalensi 6,1\%. Penelitian di Jakarta pada tahun 2016 menunjukkan prevalensi 5,7\% (Lathifah, 2017).

Rambut jangung sering disebut masyarakat dengan nama klobot selain memiliki kandungan Beta Setosterol juga mengandung bioaktif lain seperti Flavonoid. Senyawa Flavonoid yang terdapat dalam rambut jagung adalah golongan Maysin, c-glikosilflavon. Selain itu juga mengandung Volatil, Terpenoid, Derivat Sinamat, Glukosa, Rhamnosa, dan mineral (sodium, potassium, zinc, zat besi, dan klorida) (Hasanudin et al., 2012). Rambut jagung mengandung komponen bioaktif flavonoid, Saponin, Tanin, Phlobatanin, Fenol, Alkaloid, dan Glikosida jantung. Komponen tersebut menunjukkan bahwa senyawa yang ditemukan pada ekstrak rambut jagung berkontribusi terhadap bidang farmasi dan sangat baik untuk dikonsumsi oleh manusia (Sholihah et al., 2012).

Flavonoid ini menjadi sumber antioksidan yang sangat tinggi. Ismiati (2015) dalam penelitianya menjelaskan uji penangkapan radikal bebas oleh senyawa antioksidan dengan metode DPPH (1,1-diphenyl-2-picrylhydrazyl)dari rambut jagung segar sebesar 59,4\% dan kering $57,95 \%$ sedangkan pengujian dengan menggunakan metode FRAP (Ferric Reducing Antioxidant Power) dari rambut jagung segar sebesar 99,09\% dan kering 98,41\%. Ismiati (2015) menyatakan bahwa radikal bebas merupakan atom atau molekul yang sifatnya sangat tidak stabil, sangat reaktif, dan merusak jaringan. Senyawa radikal bebas timbul akibat proses kimia kompleks dalam tubuh, berupa hasil sampingan dari proses oksidasi atau pembakaran sel yang berlangsung pada waktu bernafas, metabolisme sel, olahraga berlebihan, peradangan, polusi asap kendaraan bermotor, asap rokok, bahan pencemar, radiasi matahari atau radiasi kosmis.

Bahan selain rambut jagung yang digunakan dalam proses membuat the rambut jagung yaitu ditambakan jeruk nipis dan madu sebagai bagian pelengkap dan untuk memperkaya kandungan yang bermanfaat bagi kesehatan konsumen jika mengkonsumsi produk ini. Jeruk nipis misalnya mengandung vitamin $C$, selain itu juga jeruk nipis mempu meningkatkan kekebalan tumbuh dan juga sebagai salah satu sumber antioksidan. Sedangkan madu telah terbukti dapat mengobati batuk persisten dan sakit tenggorokan, memiliki sifat anti bakteri, membantu membersihkan darah, membantu kerja ginjal dan usus, rendah kalori dan rendah lemak (Sikamdani, 2013).

Penelitian ini bertujuan untuk mengetahui 
tingkat pengetahuan mahasiswa khususnya di APIKES Citra Medika Surakarta mengenai manfaat teh rambut jagung untuk pencegahan dan pengobatan Diabetes Melitus.

\section{METODE PENELITIAN}

Cara penelitian yang digunakan dalam penelitian ini adalah non eksperimen. Penelitian survei adalah penelitian yang dilakukan tanpa melakukan intervensi terhadap subjek penelitian (masyarakat) sehingga seing disebut penelitian non eksperimen (Notoatmodjo, 2012). Penulis hanya memberikan kuesioner yang harus diisi dengan tanda check list $(\sqrt{ })$ oleh para mahasiswa dan selanjutnya mengolah jawaban yang didapat dari kuesioner. Sampel pada penelitian ini adalah berjumlah dua puluh mahasiswa APIKES Citra Medika Surakarta, Provinsi Jawa Tengah. Cara mengolah data dari hasil kuesioner ini adalah dengan memberi skoring menggunakan pendekatan skala Likert.

Analisis penelitian yang digunakan adalah analisis deskriptif yaitu penelitian yang dilakukan untuk mendeskripsikan atau menggambarkan fenomena yang terjadi di masyarakat (Notoatmodjo, 2012).

Kuesioner pada penelitian ini ditampilan di Tabel 1.

\section{HASIL DAN PEMBAHASAN HASIL PENELITIAN}

1. Hasil Pengisian Kuesioner pada Mahasiswa di Apikes Citra Medika Surakarta (Tabel 2)

Hasil penelitian menunjukkan bahwa dari 20 sampel mahasiswa yang telah mengisi kuesinoner diperoleh data sebagai berikut : Satu, untuk pertanyaan pertama $100 \%$ mahasiswa menjawab setuju, $0 \%$ menjawab ragu-ragu dan tidak tahu; dua, untuk pertanyaan kedua $85 \%$ mahasiswa menjawab setuju, 10\% mahasiswa menjawab ragu-ragu dan 3\% mahasiswa menjawab tidak setuju; tiga, untuk pertanyaan ketiga $60 \%$ mahasiswa menjawab setuju, 35\% mahasiswa menjawab ragu-ragu dan 5\% mahasiswa menjawab tidak setuju; empat, untuk pertanyaan ke empat 60\% mahasiswa menjawab setuju, 35\% mahasiswa menjawab ragu-ragu dan 5\% mahasiswa menjawab tidak setuju; lima, untuk pertanyaan kelima 95\% mahasiswa menjawab setuju, 5\% menjawab ragu-ragu dan $0 \%$ menjawab tidak tahu; enam, untuk pertanyaan keenam 70\% mahasiswa menjawab setuju, 30\% menjawan ragu-ragu dan $0 \%$ menjawab tidak tahu; tujuh, untuk pertanyaan ke tujuh 95\% mahasiswa menjawab setuju, 5\% menjawab ragu-ragu dan $0 \%$ menjawab tidak tahu; delapan, untuk pertanyaan ke delapan 90\% mahasiswa menjawab setuju' $10 \%$ menjawab ragu-ragu dan $0 \%$ menjawab tidak tahu; Sembilan, untuk pertnyaan ke Sembilan 70\% mahasiswa menjawab setuju, 30\% menjawab ragu-ragu dan $0 \%$ menjawab tidak tahu; sepuluh, untuk pertanyaan ke sepuluh $65 \%$ mahasiswa menjawab setuju, 35\% menjawab ragu-ragu dan $0 \%$ menjawab tidak tahu; sebelas, untuk pertanyaan ke sebelas $80 \%$ mahasiswa menjawab setuju, 20\% menjawab ragu-ragu dan $0 \%$ menjawab tidak tahu; dua belas, untuk pertanyaan ke dua belas $100 \%$ mahasiswa menjawab setuju, $0 \%$ menjawab ragu-ragu dan tidak tahu; tiga belas, untuk pertanyaan ke tiga belas, $100 \%$ mahasiswa menjawab setuju dan $0 \%$ mahasiswa menjawab ragu-ragu dan tidak tahu.

\section{PEMBAHASAN}

Diabetes Melitus merupakan suatu kelainan metabolik dengan ciri utama pada etiologi multifaktorial. Penyakit DM ditandai dengan hiperglikemia kronis dan selanjutnya akan mempengaruhi metabolisme karbohidrat, protein dan lemak. Pasien DM ditemukan dengan berbagai gejala seperti poliuria (banyak berkemih), polidipsia (banyak minum) dan polifagia banyak makan) dengan disertai penurunan 
Tabel 1. Kuesioner Penelitian

\begin{tabular}{|c|c|c|c|c|}
\hline No & Pertanyaan & Setuju & $\begin{array}{l}\text { Ragu- } \\
\text { Ragu }\end{array}$ & Tidak \\
\hline 1 & Tahukah Anda Tentang Penyakit Diabetes Melitus? & & & \\
\hline 2 & $\begin{array}{l}\text { Perlukah pengembangan pengetahuan tentang pencegahan da } \\
\text { penyakit Diabetes Melitus? }\end{array}$ & & & \\
\hline 3 & Tahukah Anda tentang khasiat teh rambut jagung? & & & \\
\hline 4 & Dapatkah Anda membuat teh rambut jagung? & & & \\
\hline 5 & $\begin{array}{l}\text { Setujukah Anda jika khasiat teh rambut jagung menjadi salah satu cara dalam } \\
\text { pencegahan dan pengobatan penyakit Diabetes Melitus? }\end{array}$ & & & \\
\hline 6 & Apakah teh rambut jagung memberikan manfaat yang nyata? & & & \\
\hline 7 & $\begin{array}{l}\text { Dapatkah pengembangan teh rambut jagung menjadi salah satu cara pen cegahan } \\
\text { dan pengobatan Diabetes Melitus? }\end{array}$ & & & \\
\hline 8 & $\begin{array}{l}\text { Mahasiswa perlu pengembangan pengetahuan mengenai manfaat teh rambut } \\
\text { jagung untuk pencegahan dan pengobatan Diabates Melitus. Setujukah Anda? }\end{array}$ & & & \\
\hline 9 & $\begin{array}{l}\text { Setelah minum teh rambut jagung saya merasakan, saya merasaka } \\
\text { kadar gula darah. Setujukah Anda? }\end{array}$ & & & \\
\hline 10 & $\begin{array}{l}\text { Pada hari pertama minum teh rambut jagung langsung terasa manfaatnya, saya } \\
\text { merasa tidak cepat lapar, tidak cepat haus dan tidak cepat lelah. Setujukah Anda? }\end{array}$ & & & \\
\hline 11 & $\begin{array}{l}\text { Pada hari ke dua saya minum the rambut jagung, saya merasakan efek yang } \\
\text { berbeda dari biasanya, kebiasaan bunag air kecil malam hari menjadi lebih jarang. } \\
\text { Setujukah Anda? }\end{array}$ & & & \\
\hline 12 & $\begin{array}{l}\text { Saya senang mengikuti sosialisasi pengembangan manfaat teh rambut jagung } \\
\text { sebagai salah satu dalam cara penc egahan dan pengobatan Diabetes Melitus. } \\
\text { Setujukah Anda? }\end{array}$ & & & \\
\hline 13 & $\begin{array}{l}\text { Pengembangan manfaat teh rambut jagung dapat menjadi salah satu cara dalam } \\
\text { pencegahan dan pengobatan Diabetes Melitus. Setujukah Anda? }\end{array}$ & & & \\
\hline
\end{tabular}

Tabel 2. Hasil Pengisian Kuesioner pada Mahasiswa di Apikes Citra Medika Surakarta

\begin{tabular}{|c|l|c|c|c|}
\hline No & \multicolumn{1}{|c|}{ Pertanyaan } & $\begin{array}{c}\text { Setuju } \\
(\%)\end{array}$ & $\begin{array}{c}\text { Ragu- } \\
\text { Ragu } \\
(\%)\end{array}$ & $\begin{array}{c}\text { Tidak } \\
(\%)\end{array}$ \\
\hline 1 & Tahukah Anda Tentang Penyakit Diabetes Melitus? & 100 & 0 & 0 \\
\hline 2 & $\begin{array}{l}\text { Perlukah pengembangan pengetahuan tentang pencegahan dan pengobatan } \\
\text { penyakit Diabetes Melitus? }\end{array}$ & 85 & 10 & 5 \\
\hline 3 & Tahukah Anda tentang khasiat teh rambut jagung? & 60 & 25 & 15 \\
\hline 4 & Dapatkah Anda membuat teh rambut jagung? & 60 & 35 & 5 \\
\hline 5 & $\begin{array}{l}\text { Setujukah Anda jika khasiat teh rambut jagung menjadi salah satu cara dalam } \\
\text { pencegahan dan pengobatan penyakit Diabetes Melitus? }\end{array}$ & 95 & 5 & 0 \\
\hline 6 & Apakah teh rambut jagung memberikan manfaat yang nyata? & 70 & 30 & 0 \\
\hline 7 & $\begin{array}{l}\text { Dapatkah pengembangan teh rambut jagung menjadi salah satu cara penc egahan } \\
\text { dan pengobatan Diabetes Melitus? }\end{array}$ & 95 & 5 & 0 \\
\hline 8 & $\begin{array}{l}\text { Mahasiswa perlu pengembangan pengetahuan mengenai manfaat teh ram but } \\
\text { jagung untuk pencegahan dan pengobatan Diabates Melitus. Setujukah Anda? }\end{array}$ & 90 & 10 & 0 \\
\hline 9 & $\begin{array}{l}\text { Setelah minum teh rambut jagung saya merasakan, saya merasakan penurunan } \\
\text { kadar gula darah. Setujukah Anda? }\end{array}$ & 70 & 30 & 0 \\
\hline 10 & $\begin{array}{l}\text { Pada hari pertama minum teh rambut jagung langsun g terasa manfaatnya, saya } \\
\text { merasa tidak cepat lapar, tidak cepat haus dan tidak cepat lelah. Setujukah Anda? }\end{array}$ & 65 & 35 & 0 \\
\hline 11 & $\begin{array}{l}\text { Pada hari ke dua saya minum teh rambut jagung, saya merasakan efek yang } \\
\text { berbeda dari bia sanya, kebiasaan bunag air keci l di malam hari m enjadi lebih } \\
\text { jarang. Setujukah Anda? }\end{array}$ & 80 & 20 & 0 \\
\hline 12 & $\begin{array}{l}\text { Saya senang mengikuti sosialisasi pengembangan manfaat teh rambut jagung } \\
\text { sebagai salah satu dalam cara penc egahan dan pengobatan Diabetes Melitus. } \\
\text { Setujukah Anda? }\end{array}$ & 100 & 0 & 0 \\
\hline 13 & $\begin{array}{l}\text { Pengembangan manfaat teh rambut jagung dapat menjadi salah satu cara dalam } \\
\text { pencegahan dan pengobatan Diabetes Melitus. Setujukah Anda? }\end{array}$ & 100 & 0 & 0 \\
\hline
\end{tabular}

berat badan. DM pada jangka waktu yang lama akan menimbulkan rangkaian gangguan metabolik yang menyebabkan kelainan patologis makrovaskular dan mikrovaskular (Azrimaidaliza, 2011).

Seiring dengan kecenderungan peningkatan pasien Penyakit DM, terlihat juga adanya peningkatan prevalensi pasien obesitas umum dan obesitas sentral (bagian perut). Pada tahun 2007, prevalensi penderita obesitas umum pada penduduk umur di atas 15 tahun di Indonesia, yaitu $10,3 \%$. Sebanyak 12 propinsi mempunyai prevalensi penderita obesitas umum pada penduduk umur di atas 15 tahun di atas prevalensi nasional. Sedangkan prevalensi nasional obesitas sentral pada penduduk umur di atas 15 tahun menunjukkan angka lebih tinggi dibanding obesitas umum, yaitu pada angka $18,8 \%$. Sebanyak 17 propinsi mempunyai prevalensi penderita obesitas sentral pada penduduk umur di atas 15 tahun di atas prevalensi nasional. Berbagai teori dan penelitianpenelitian yang sudah dilakukan menemukan bahwa kenaikan berat badan melebihi normal atau obesitas akan meningkatkan resiko bahkan dikatakan sebagai faktor resiko utama 
terjadinya DM. Pada anak dengan DM tipe 2, sekitar $85 \%$ maka anak tersebut memiliki kelebihan berat badan atau mengalami obesitas. Selain faktor obesitas, faktor resiko lain yang berperan terhadap terjadinya Penyakit DM, antara lain adalah faktor genetik, pertambahan usia, kurangnya aktifitas fisik dan pola makan tidak seimbang yang memicu terjadinya obesitas. Pola makan berupa asupan makanan tinggi energi dan tinggi lemak tanpa disertai dengan aktifitas fisik yang teratur akan mengubah keseimbangan energi dengan disimpannya energi sebagai lemak simpanan yang jarang digunakan. Asupan energi yang berlebihan akan meningkatkan resistensi insulin sekalipun belum terjadi kenaikan berat badan yang signifikan. Diet tinggi kalori, tinggi lemak dan rendah karbohidrat berkaitan dengan DM tipe 2 (Arisman, 2011).

Bagian-bagian tanaman jagung telah banyak dimanfaatkan oleh masyarakat sebagai obat tradisional, salah satunya adalah bagian rambut jagung yang merupakan limbah industri pangan. Ekstrak air rambut jagung menunjukan hasil positif untuk penyembuhan gagal ginjal pada tikus (Wirasutisna dkk, 2012).

Walaupun telah banyak dimanfaatkan, penelitian mengenai kandungan kimia dalam rambut jagung masih terbatas dan belum banyak dipublikasi. Oleh karena itu, penelitian ini bertujuan untuk menelaah kandungan kimia rambut jagung sehingga dapat digunakan sebagai acuan dalam pengembangannya sebagai obat tradisional. Penelitian ini juga memiliki nilai tambah karena mendukung pemanfaatan limbah. Langkah-langkah yang dilakukan untuk mengisolasi senyawa dari rambut jagung dimulai dari proses ekstraksi dengan metode yang sesuai, fraksinasi, pemurnian, uji kemurnian dan karakterisasi isolat (Wirasutisna dkk, 2012).

Zea mays L. dengan nama Indonesia Jagung adalah tanaman yang banyak dibudidayakan di Indonesia. Berdasarkan penelitian mengungkapkan bahwa rambut jagung memiliki komponen senyawa fenol, flavonoid dan karoten yang memiliki aktivitas antioksidan dan tabir surya. Antioksidan adalah senyawa yang digunakan untuk mencegah terjadinya penyakit degeneratif yang disebabkan oleh radikal bebas. Pemicu dari adanya radikal bebas adalah asap rokok, radiasi, polusi udara dari pabrik-pabrik dan makanan yang telah terkontaminasi radikal bebas. Radikal bebas ini bersifat reaktif dan berbahaya, jika jumlah radikal bebas didalam tubuh berlebih maka perlu adanya asupan antioksidan dari luar. Antioksidan bermanfaat menetralkan radikal bebas yang sifatnya reaktif, antioksidan akan melumpuhkan radikal bebas dan menghambat proses kerusakan. Antioksidan merupakan senyawa yang akan menghambat atau menunda proses oksidasi substrat pada konsentrasi yang rendah. Salah satu sumber antioksidan alami adalah sayuran, buah-buahan dan daun yang kaya senyawa fenol (Kusriani dkk, 2017).

Berdasarkan hasil penelitian Mansur dkk (2017) didapatkan data sebgaai berikut : Berdasarkan penelitian yang telah dilakukan dapat diambil kesimpulan bahwa krim a/m ekstrak etanol rambut jagung pada konsentrasi $3 \%, 5 \%$ dan $7 \%$ dapat mempercepat proses penyembuhan luka hiperglikemia yang terlihat pada persentase penyembuhan luka. Di mana hasil terbaik diperoleh pada konsentrasi 7\% sebab mempunyai persentase penyembuhan yang paling cepat dibanding konsentrasi $3 \%$ dan $5 \%$ serta mencapai persentase $100 \%$ pada hari ke-7 setelah pemberian krim rajabetrin selama dua kali sehari.

Wawasan masyarakat yang kurang tentang manfaat teh rambut jagung memang masih sedikit sehingga diperlukan adanya sosialisasi. Masyarakat diketahui sering kali mengacuhkan limbah rambut jagung ini dan sudah terbiasa membuangnya tanpa memanfaatkannya menjadi sesuatu yang bermanfaat untuk kesehatan. Berdasarkan hasil quesioner yang 
diberikan kepada dua puluh mahasiswa Apikes Citra Medika dapat dibahas sebagai berikut : $100 \%$ mahasiswa memahami tentang penyakit Diabetes Melitus, 85\% mahasiswa setuju diadakan pengembangan pengetahuan tentang pencegahan dan pengobatan penyakit Diabetes Melitus, 60\% mahasiswa tidak mengetahui khasiat atau manfaat the rambut jagung, 60\% mahasiswa mengaku dapat membuat ramuan teh rambut jagung, 95\% mahasiswa setuju dengan khasiat teh rambut jagung menjadi salah satu cara dalam pencegahan dan pengobatan penyakit Diabetes Melitus, 70\% mahasiswa mengatakan bahwa teh rambut jagung memberikan manfaat yang nyata, $90 \%$ mahasiswa mengatakan setuju bahwa mahasiswa perlu pengembangan pengetahuan mengenai manfaat teh rambut jagung untuk pencegahan dan pengobatan Diabates Melitus, 70\% mahasiswa mengatakan setelah minum teh rambut jagung merasakan penurunan kadar gula darah, 65\% mahasiswa mengatakan pada hari pertama minum teh rambut jagung langsung terasa manfaatnya, yaitu merasa tidak cepat lapar, tidak cepat haus dan tidak cepat lelah, 80\% mahasiswa mengatakan pada hari ke dua saya minum teh rambut jagung, merasakan efek yang berbeda dari biasanya, kebiasaan bunag air kecil di malam hari menjadi lebih jarang, 100\% mahasiswa mengatakan senang mengikuti sosialisasi pengembangan manfaat teh rambut jagung sebagai salah satu dalam cara pencegahan dan pengobatan Diabetes Melitus dan $100 \%$ mahasiswa mengatakan pengembangan manfaat teh rambut jagung dapat menjadi salah satu cara dalam pencegahan dan pengobatan Diabetes Melitus.

Berdasarkan hasil sosialisai dan penelitian menggunakan quesioner tersebut dapat disimpulkan bahwa sebagian besar mahasiswa sudah mengetahui tentang penyakit Diabetes Melitus dan manfaat teh rambut jagung yang antara lain dapat bermanfaat untuk kesehatan yaitu mencegah dan mengobati penyakit Diabtes Melitus. Selain hal tersebut ternyata sebagian bersar mahasiswa merasakan manfaat nyata dari konsumsi teh rambut jagung selama tiga hari, yaitu terjadi penurunan kadar gula darah, tidak cepat ngantuk, tidak cepat lelah dan tidak sering buang air kecil pada malam hari. Mahasiswa juga sangat antusias terhadap pengembangan pengetahuan mengenai manfaat teh rambut jagung untuk pencegahan dan pengobatan Diabates Melitus.

Manfaat teh rambut jagung ini juga sesuai dengan hasil penelitian Sikamdani dkk (2012) yang mengatakan bahwa pada pemberian ekstrak rambut jagung diketahui bahwa ekstrak secara signifikan memberikan pengaruh terhadap penurunan kadar gula darah pada mencit, hasil penelitian Ramadani dkk (2016) yang mengatakan bahwa pengetahuan mengenai manfaat teh rambut jagung untuk pencegahan dan pengobatan Diabates Melitus, hasil penelitian Koloay dkk (2015) yang mengatakan bahwa ekstrak etanol rambut jagung (Zea mays L.) memiliki efek untuk menurunkan kadar gula darah pada tikus putih jantan galur wistar yang diinduksi aloksan dan dosis yang paling efektif ialah $2,52 \mathrm{~g} / \mathrm{KgBB}$, hasil penelitian Kamilah dkk (2015) mengatakan bahwa dalam uji metabolit sekunder teh rambut jagung terdapat senyawa flavanoid, tannin dan saponin yang berarti sesuai dengan tinjauan pustaka yang didapat. Lalu berdasarkan hasil uji organoleptik yang dilakukan berdasarkan tingkat kesukaan :66,7\% orang memilih suka, warna : 63,3\% orang memilih warna kuning kecoklatan, bau : 76,7\% orang memilih bau jagung dan rasa : 73,33\% orang memilih rasa jagung. Berarti sampel teh dari rambut jagung memiliki mutu yang baik yaitu bertahan lama jika disimpan, tidak mudah rusak, zat antioksidan yang terkandung didalamnya dapat dirasakan manfaatnya dan memili kadar serat yang dibutuhkan oleh tubuh. 


\section{KESIMPULAN DAN SARAN}

Hasil penelitian menunjukkan bahwa dari 20 sampel mahasiswa yang telah mengisi kuesinoner untuk pertanyaan sikap dan tindakan diperoleh data sebagai berikut:

1. Sebagian besar mahasiswa sudah mengetahui tentang penyakit Diabetes Melitus dan manfaat teh rambut jagung yang antara lain dapat bermanfaat untuk kesehatan yaitu mencegah dan mengobati penyakit Diabtes Melitus

2. Sebagian bersar mahasiswa merasakan manfaat nyata dari konsumsi teh rambut jagung selama tiga hari, yaitu terjadi penurunan kadar gula darah, tidak cepat ngantuk, tidak cep at lelah dan tidak sering buang air kecil pada malam hari.

3. Mahasiswa sangat antusias terhadap pengembangan pengetahuan mengenai manfaat teh rambut jagung untuk pencegahan dan pengobatan Diabates Melitus.

\section{DAFTAR PUSTAKA}

Arisman. 2011. Obesitas, Diabetes Melitus, \& Dislipidemia: Konsep, Teori, dan Penangan Aplikatif. Jakarta: EGC.

Azrimaidaliza. 2011. "Asupan Zat Gizidanpenyakit DiabetesMelitus". Jumal Kesehatan Masyarakat, September 2011-Maret 2011,Vol. 6, No.1.

Gustaviani, Reno. 2006. Diagnosa dan Klasifiksi Diabetes Melitus. Buku Ajar Ilmu Penyakit Dalam jilid III. Hal. 1857-1859. Jakarta : Pusat Penerbit Departemen Ilmu Penyakit Dalam FK UI.

Hasanudin, Khairunnisa, Puziah Hasyim, dan Shuhaimi Mustafa. 2012. "Corn Silk (Stigma maydis) in Healthcare: A Phytochemical and Pharmalogical Review". Journal Molecules. 17: 9697-9715.

Ismiati, Erna Retno. 2015. “Aktivitas Antioksidan Minuman Herbal Rambut Jagung Dengan Variasi Kondisi Dan Lama Perebusan". Skripsi. Surakarta : Program Studi Pendidikan Biologi UMS.
Kamilah, Atun; Amalia, Atika dan Yuni, Cici Yesi Rahma dan Arif, Ridwan. 2015. "Analisis Dan Pembuatan Teh Dari Rambut Jagung (Zea Mays L. Sacharata)". Jurnal SMK SMAK Padang.

Koloay, Kristover; Citraningtyas, Gayatri dan Lolo, Widya Astuty. 2015. "Uji Efektivitas Ekstrak Etanol Rambut Jagung

(Zea Mays L.) Terhadap Penurunan Kadar Gula Darah Tikus Putih Jantan Galur Wistar (Rattus Norvegicus L.) Yang Diinduksi Aloksan”. PHARMACON Jurnal Ilmiah Farmasi - UNSRAT Vol. 4 No. 3 Agustus 2015 ISSN 2302 $-2493$.

Kusrinai, Herni; Marliani, Lia; dan Apriliani, Erlina, 2017. "Aktivitas Antioksidan dan Tabir Surya dari Tongkol dan Rambut Jagung (Zea mays L.)”. IJPST Volume 4, Nomor 1.

Lathifah, Nur Lailatul. 2017. "Hubungan Durasi Penyakit Dan Kadar Gula Darah Dengan Keluhan Subyektif Penderita Diabetes Melitus". Jurnal Berkala Epidemiologi, Volume 5 Nomor 2, Mei 2017, hlm. 231-239.

Mansur, Arwidya Putri; Septiman, Azizah Pridayanti; Rahman, Nurul Fauziyah; Aulia, Andi Feni Mufti; Sari, Iis Nirma Wana; Bachtiar, Rini R. Krim Rajabetrin: "Uji Efektivitas Sediaan Krim Limbah Rambut Jagung (Zea Mays L.) Terhadap Penyembuhan Luka Mencit Diabetes Mellitus". Hasanuddin Student Journal Vol. 1 No. (2): 144-150, Desember 2017 P-ISSN: 2579-7859, E-ISSN: 2579-7867.

Ramadani, Finlinda Hery; Intannia, Difa dan Ni'mah, Malikhatun, 2016. "pengetahuan mengenai manfaat teh rambut jagung untuk pencegahan dan pengobatan Diabates Melitus". Jurnal Pharmascience, Vol 3, No. 1, Februari 2016, hal: 37 - 44. ISSN-Print. 2355 - 5386. ISSN-Online. 2460-9560.

Sikamdani, Indah Ayu. 2012. "Aktivitas Antioksidan Minuman Herbal Rambut Jagung Dengan Variasi Kondisi Dan Lama Perebusan". Karya Tulis Ilmiah. Malang : Akademi Analis Farmasi dan Makanan Putra Indonesia.

Sikamdani, Indah Ayu. 2013. “Aktivitas Ekstrak Rambut Jagung (Zea mays L.) Sebagai Penurun Kadar Gula Darah pada Mencit Putih Jantan (Mus musculus)". Naskah Publikasi. Malang: Putra Indonesia.

Sholihah, M. A., Wan Rosli, W. I., dan Nurhanan, A. R. 2012. "Phytochemicals Screening and Total Phenolic Content of Malaysian Zea mays Hair Extract”. International Food Research Journal. 19(4): 1533-1538.

Wirasutisna, Komar Ruslan; Fidrianny, Irda; Rahmayani, Annisa. 2012. "Telaah Kandungan Kimia Rambut Jagung (Zea mays L.)". Acta Pharmaceutica Indonesia, Vol. XXXVII, No. 1,2012-5. 